\title{
Energy balance and diurnal variation in methane production as affected by feeding frequency in Jersey cows in late lactation
}

\author{
J. V. Judy, ${ }^{\star}$ G. C. Bachman,† T. M. Brown-Brandl,‡ S. C. Fernando, ${ }^{*}$ K. E. Hales,ł P. S. Miller, ${ }^{*}$ R. R. Stowell, ${ }^{\star}$ \\ and P. J. Kononoff*1 \\ *Department of Animal Science, and \\ †Department of Biological Science, University of Nebraska-Lincoln, Lincoln 68583 \\ fUSDA, Agricultural Research Service, US Meat Animal Research Center, Clay Center, NE 68933
}

\section{ABSTRACT}

Methane $\left(\mathrm{CH}_{4}\right)$ production of ruminants typically increases with increased dry matter intake (DMI). However, few studies have observed the effects of feeding multiple times a day and its effects on diurnal variation in $\mathrm{CH}_{4}$ production and energy balance in late-lactation dairy cattle. A study using headbox-style indirect calorimetry and 12 multiparous $(225 \pm 16.2 \mathrm{~d}$ in milk; mean $\pm \mathrm{SD}$ ) lactating Jersey cows was conducted to determine the effects of feeding twice daily on diurnal variation in $\mathrm{CH}_{4}$ production and total energy balance. A crossover design with 14-d periods (10 d of adaption and $4 \mathrm{~d}$ of collection) was used to compare 2 treatments. Treatments consisted of either once a day feeding $(1 \times ; 100 \%$ of feed given at $1000 \mathrm{~h})$ or twice a day feeding $(2 \times ; 50 \%$ of feed given at $1000 \mathrm{~h}$ and the final $50 \%$ at $2000 \mathrm{~h}$ ) with a common diet fed in both treatments. Dry matter intake was not different between treatments, with a mean of $16.9 \pm 0.88 \mathrm{~kg} / \mathrm{d}$. Once a day feeding tended to have greater milk yield compared with twice a day feeding (21.2 vs. $20.4 \pm 1.59$ $\mathrm{kg} / \mathrm{d}$, respectively). Milk fat and milk protein percentage were not different, with means of $6.18 \pm 0.20 \%$ and $3.98 \pm 0.08 \%$, respectively. Total $\mathrm{CH}_{4}$ production did not differ between treatments, with a mean of 402.1 $\pm 20.8 \mathrm{~L} / \mathrm{d}$. Similarly, $\mathrm{CH}_{4}$ per unit of milk yield and DMI was not different between treatments, with means of $20.5 \pm 1.81$ and $23.8 \pm 1.21 \mathrm{~L} / \mathrm{kg}$, respectively. Feeding frequency did not affect diurnal variation of hourly $\mathrm{CH}_{4}$ production, with a mean of $17.1 \pm 0.74 \mathrm{~L} / \mathrm{h}$. A trend was observed for a treatment $\times$ hour interaction. Methane production per hour increased after the second feeding for cattle fed twice versus once daily. Gross energy, digestible energy, metabolizable energy, and balance (milk plus tissue) per kilogram of DMI did

\footnotetext{
Received February 15, 2018.

Accepted August 9, 2018.

${ }^{1}$ Corresponding author: pkononoff2@unl.edu
}

not differ by feeding frequency, with means of $4.41 \pm$ $0.01,3.05 \pm 0.03,2.63 \pm 0.03$, and $1.32 \pm 0.08 \mathrm{Mcal} /$ $\mathrm{kg}$ of DM, respectively. Metabolizable energy for maintenance was $146 \mathrm{kcal} / \mathrm{kg}$ of metabolic body weight, with an efficiency of converting metabolizable energy to net energy balance (milk plus tissue) of $76 \%$. Nitrogen balance did not differ among treatments, with a mean balance of $17.3 \pm 13.0 \mathrm{~g} / \mathrm{d}$. Therefore, total $\mathrm{CH}_{4}$ production and energy maintenance were not affected by feeding frequency. However, $\mathrm{CH}_{4}$ was variable throughout the day, and caution should be exercised when collecting $\mathrm{CH}_{4}$ samples at a limited number of time points because this may under- or overestimate total production.

Key words: dairy cow, diurnal variation, energy, methane

\section{INTRODUCTION}

Accurate measurement of methane $\left(\mathrm{CH}_{4}\right)$ production is needed for energy-balance studies to correctly partition where energy is being used in the animal. Collecting accurate measures of gas production by livestock is a laborious task. In cattle, the release of $\mathrm{CH}_{4}$ from the rumen is episodic, which may contribute to the challenge of accurate emission measurements (Hegarty, 2013). It is well established that $\mathrm{CH}_{4}$ production can be altered by manipulation of the diet by including more fat and grains (Knapp et al., 2014). Feeding practices are also known to affect gas production. This includes time between feedings and frequency of feedings, but gas production may also be affected by the number of meals consumed, fermentation rate, and fermentation patterns (Brask et al., 2015). Methane production is dependent on feed consumption and digestion and can vary from 0.14 to $0.51 \mathrm{~L} / \mathrm{min}$ throughout the day (Crompton et al., 2011).

In a recent study using lactating dairy cows, Brask et al. (2015) described 2 peaks of $\mathrm{CH}_{4}$ production over a 24 -h period. The first, a minor peak, occurred after the morning feeding, whereas the second, a major peak, 
occurred after the evening feeding. Similarly, Hollmann et al. (2013) described a small peak of $\mathrm{CH}_{4}$ after the morning feeding followed by a major peak after the afternoon feeding. Other research has described the greater peak for $\mathrm{CH}_{4}$ production as occurring after the morning feeding, whereas after the second feeding the peak was lower in lactating dairy cattle (Crompton et al., 2011). The increased $\mathrm{CH}_{4}$ production occurred approximately 120 and 60 min postfeeding for morning and afternoon feedings, respectively. In a study using sheep restricted to $95 \%$ of ad libitum intake fed 1 meal per day, van Zijderveld et al. (2010) observed a single peak 4 to $6 \mathrm{~h}$ after that feeding. Interestingly, peak $\mathrm{CH}_{4}$ production was reduced in sheep supplemented with nitrate, and sheep supplemented with sulfate produced less $\mathrm{CH}_{4}$, but the observed response was delayed until $10 \mathrm{~h}$ postfeeding. In beef cattle, Hales and Cole (2017) fed beef steers once daily and observed peak $\mathrm{CH}_{4}$ production around 4 to $6 \mathrm{~h}$ postfeeding. Although this research has been insightful, very little research in the area has included Jersey cattle in confined feeding systems fed a TMR, and it is known that eating and ruminating behaviors differ between breeds. For example, Aikman et al. (2008) observed that compared with Holsteins, Jersey cattle had a more even distribution of meals throughout the day and increased chewing time; this in turn may affect rumen fermentation and gas production.

Over the last several decades, the maintenance energy requirement for dairy cattle is believed to have increased due to genetic improvement (Moraes et al., 2015). Reported estimates of maintenance requirements have ranged from 110 to $208 \mathrm{kcal} / \mathrm{kg}$ of metabolic BW (MBW; Flatt et al., 1967; Foth et al., 2015). The majority of the experiments with dairy cattle have studied cows at peak or shortly after peak milk production. The estimation of maintenance in high-producing dairy cows is challenging because they may be in negative energy balance and, as a result, be utilizing body energy stores. Lactation demands a tremendous amount of energy and alters normal function to compensate (Bauman and Currie, 1980). Hence, lactating dairy cattle in a negative energy balance may have an altered metabolic state (Fenwick et al., 2008), and cows may have a greater maintenance energy requirement early in lactation. Dairy cattle in mid to late lactation may be better suited for calculating maintenance requirements. Observations using these cattle are less variable because these cattle are past peak milk production and not mobilizing large quantities of body energy stores. However, little research is available on energy balance in late-lactation dairy cattle, especially those of the Jersey breed, and is needed to further develop models for energy requirements throughout the lactation cycle. The objectives of this study were to characterize diurnal $\mathrm{CH}_{4}$ production in late-lactation Jersey dairy cattle being fed either once or twice daily while also measuring energy utilization.

\section{MATERIALS AND METHODS}

All animal care and experimental procedures were approved by the University of Nebraska-Lincoln Animal Care and Use Committee. Twelve multiparous lactating Jersey cows $(225 \pm 16.2 \mathrm{DIM}$; mean $\pm \mathrm{SD})$ with a BW averaging $480 \pm 12.2 \mathrm{~kg} / \mathrm{d}$ were used. Cattle were individually weighed twice during the collection week after the morning milking, with the average used to determine BW. At the end of the experiment, no cattle were more than $90 \mathrm{~d}$ pregnant. All cows were housed in a temperature-controlled barn at the Dairy Metabolism Facility at the Animal Science Complex at the University of Nebraska-Lincoln and were milked at 0700 and $1800 \mathrm{~h}$ in individual tiestalls equipped with rubber mats. All animals were in the facility for all previous days of their lactation, and they were offered feed once per day during this time before the start of the study.

The experimental design was a 2-period crossover design. Cows were randomly assigned to 1 of 2 treatments: a conventional once-daily feeding or a twicedaily feeding. Treatments alternated over 2 experimental periods, and during each period measurements were collected on each animal on each treatment. The study was conducted with a total of 2 experimental periods, each being $14 \mathrm{~d}$ in duration. Each period included 10 $\mathrm{d}$ for ab libitum treatment adaptation, targeting about $5 \%$ refusals during that time, followed by $4 \mathrm{~d}$ of collection of $95 \%$ ad libitum feeding to reduce the amount of refusals. The $95 \%$ ad libitum feed intake was calculated using the average of the previous $4 \mathrm{~d}$ of feed intake and remained constant during the collection week. Refusals were weighed and sampled the following morning each day during the experiment, and the cattle were given fresh feed at that time. The same diet was fed to all cattle. The chemical composition and analysis of the diet and feed ingredients are presented in Tables 1 and 2 , with gross energy calculated using a bomb calorimeter (6400 Calorimeter, Parr, Moline, IL). The CornellPenn-Miner dairy model (Boston et al., 2000) was used to balance the diet. All dietary treatments contained corn silage $(37.7 \%$ of diet DM), alfalfa hay $(14.0 \%$ of diet $\mathrm{DM})$, and brome hay (2.56\% of diet DM), and the remaining ( $45.7 \%$ of diet $\mathrm{DM})$ was a concentrate mixture that was combined as a TMR. The TMR was mixed in a Calan Data Ranger (American Calan Inc., Northwood, NH) and fed either once daily at $1000 \mathrm{~h}$ or twice daily at 1000 and 2000 h. For cattle fed twice 
Table 1. Chemical composition and analysis of diet formulated to measure diurnal variation of methane and measure energy balance of late-lactation Jersey cows $(225 \pm 16.2$ DIM; mean $\pm \mathrm{SD})$

\begin{tabular}{|c|c|}
\hline Item & Value \\
\hline \multicolumn{2}{|l|}{ Ingredient, \% DM } \\
\hline Corn silage & 37.7 \\
\hline Alfalfa hay & 14.0 \\
\hline Brome hay & 2.56 \\
\hline Ground corn & 17.1 \\
\hline Soybean meal & 14.0 \\
\hline Bypass soy $^{1}$ & 4.66 \\
\hline Soybean hulls & 2.56 \\
\hline Tallow (porcine) & 1.98 \\
\hline Blood meal & 1.56 \\
\hline Calcium carbonate & 1.40 \\
\hline Ca salts of long-chain fatty acids ${ }^{2}$ & 0.82 \\
\hline Sodium bicarbonate & 0.58 \\
\hline Dicalcium phosphate & 0.35 \\
\hline Magnesium oxide & 0.33 \\
\hline Salt & 0.26 \\
\hline Bypass methionine $^{3}$ & 0.07 \\
\hline Bypass lysine $^{4}$ & 0.05 \\
\hline Trace mineral premix ${ }^{5}$ & 0.05 \\
\hline Vitamin premix ${ }^{6}$ & 0.04 \\
\hline \multicolumn{2}{|l|}{ Chemical composition $^{7}$} \\
\hline DM, \% & $61.8(0.01)$ \\
\hline $\mathrm{CP}, \%$ of $\mathrm{DM}$ & $18.5(0.25)$ \\
\hline Crude fat, $\%$ of DM & $4.22(0.22)$ \\
\hline $\mathrm{ADF}, \%$ of $\mathrm{DM}$ & $16.6(0.02)$ \\
\hline $\mathrm{NDF}, \%$ of DM & $25.6(0.15)$ \\
\hline Lignin, \% of DM & $3.76(0.20)$ \\
\hline Ash, $\%$ of DM & $7.98(0.02)$ \\
\hline Starch, \% of DM & $28.7(0.57)$ \\
\hline Gross energy, ${ }^{8} \mathrm{Mcal} / \mathrm{kg}$ & $4.42(0.09)$ \\
\hline $\mathrm{ME},{ }^{9} \mathrm{Mcal} / \mathrm{kg}$ & 2.77 \\
\hline $\mathrm{NE}_{\mathrm{L}},{ }^{9} \mathrm{Mcal} / \mathrm{kg}$ & 1.79 \\
\hline
\end{tabular}

${ }^{1}$ Soypass (LignoTech, Overland Park, KS).

${ }^{2}$ Megalac (Church \& Dwight Co. Inc., Princeton, NJ).

${ }^{3}$ SmartamineM (Adisseo, Antony, France).

${ }^{4}$ Ajipro-L (Ajinomoto Heartland Inc., Chicago, IL).

${ }^{5}$ Formulated to supply approximately $2,300 \mathrm{mg} / \mathrm{kg}$ of Co, $25,000 \mathrm{mg} /$ $\mathrm{kg}$ of $\mathrm{Cu}, 2,600 \mathrm{mg} / \mathrm{kg}$ of I, $1,000 \mathrm{mg} / \mathrm{kg}$ of Fe, $150,000 \mathrm{mg} / \mathrm{kg}$ of Mn, $820 \mathrm{mg} / \mathrm{kg}$ of Se, and $180,000 \mathrm{mg} / \mathrm{kg}$ of $\mathrm{Zn}$ in total rations.

${ }^{6}$ Formulated to supply approximately $148,500 \mathrm{IU} / \mathrm{d}$ of vitamin A, $38,500 \mathrm{IU} / \mathrm{d}$ of vitamin $\mathrm{D}$, and $902 \mathrm{IU} / \mathrm{d}$ of vitamin $\mathrm{E}$ in total rations.

${ }^{7}$ Values [mean (SD)] determined by Cumberland Valley Analytical Services (Hagerstown, MD).

${ }^{8}$ Values [mean (SD)] determined from composite samples from experiment and analyzed at the University of Nebraska-Lincoln.

${ }^{9}$ Values formulated from the Cornell-Penn-Miner dairy model (Boston et al., 2000).

daily, $50 \%$ of the feed was delivered during the first feeding and the other $50 \%$ was delivered during the second feeding. Minimal refusals before the second feeding were targeted after the morning feeding for the cattle fed twice daily.

\section{Laboratory Analysis}

All forages and the concentrate were sampled (500 g) on the first day of each collection period and frozen at $-20^{\circ} \mathrm{C}$. A subsample of these was sent to Cumberland
Valley Analytical Services Inc. (Waynesboro, PA) for complete nutrient analysis of DM (AOAC International, 2000), N (Leco FP-528 N Combustion Analyzer, Leco Corp., St. Joseph, MO), NDF with sodium sulfite (Van Soest et al., 1991), ADF (method 973.18; AOAC International, 2000), lignin (Goering and Van Soest, 1970), NFC [100 - (\% NDF + \% CP + \% fat $+\%$ ash)], sugar (DuBois et al., 1956), starch (Hall, 2009), crude fat (method 2003.05; AOAC International, 2006), ash (method 943.05; AOAC International, 2000), and minerals (method 985.01; AOAC International, 2000). Total mixed rations were also sampled (500 g) on each day of each collection period and were frozen at $-20^{\circ} \mathrm{C}$. The samples were then composited by period and treatment. Particle size of the TMR was determined according to Heinrichs and Kononoff (2002) using the Penn State Particle Separator. Each day of the collection period, refusals were sampled at $0900 \mathrm{~h}$ and frozen at $-20^{\circ} \mathrm{C}$. The TMR samples were analyzed at the University of Nebraska-Lincoln laboratory for DM (AOAC International, 2000), N (FlashSmart N/Protein Analyzer, CE Elantech Inc., Lakewood, NJ), NDF with sodium sulfite (Van Soest et al., 1991), starch (Hall, 2009), and ash (method 943.05; AOAC International, 2000).

Total fecal and urine output was collected from each individual cow during the collection period for 4 consecutive days. A $137 \times 76 \mathrm{~cm}$ rubber mat (Snake River Supply, Idaho Falls, ID) was placed behind the cow to collect feces. The feces were deposited multiple times a day from the rubber mats into a large garbage container (Rubbermaid, Wooster, $\mathrm{OH}$ ) with a black garbage bag covering the top to reduce $\mathrm{N}$ losses before subsampling. The feces were subsampled ( $4 \%$ wet basis) every day for 4 consecutive days and dried at $60^{\circ} \mathrm{C}$ in a forced-air oven for $48 \mathrm{~h}$ and then composited by cow and period before being ground to pass through a 1-mm screen (Wiley mill, Arthur H. Thomas Co., Philadelphia, PA). The ground feces samples were analyzed at the University of Nebraska-Lincoln laboratory for analysis of DM, N, NDF with sodium sulfide, starch, and ash using previously discussed methods. Total urine was collected by inserting a 30-cc French Foley catheter into each cow's bladder with a stylus (Tamura et al., 2014). The balloon was inflated to $50 \mathrm{~mL}$ with physiological saline, and urine was drained using Tygon tubing (Saint Gobain, La Defense, Courbevoie, France) into a plastic carboy (15 quart) behind the cow. Using the funnel spout of the plastic carboy, urine was deposited into a 55-L plastic container 4 times a day and was acidified with $50 \mathrm{~mL}$ of $\mathrm{HCl}$ (2\% wet basis) and frozen at $-20^{\circ} \mathrm{C}$ every day of the collection period. Before analysis, urine was thawed, composited by cow and period, and boiled to remove the water content. To 
Table 2. Feed chemical analysis for alfalfa hay, brome hay, corn silage, and concentrate mix (DM basis) ${ }^{1}$

\begin{tabular}{|c|c|c|c|c|c|c|c|c|}
\hline $\begin{array}{l}\text { Chemical, \% of DM } \\
\text { unless noted }\end{array}$ & \multicolumn{2}{|c|}{ Alfalfa } & \multicolumn{2}{|c|}{ Brome hay } & \multicolumn{2}{|c|}{ Corn silage } & \multicolumn{2}{|c|}{ Concentrate } \\
\hline DM, \% & 88.2 & 0.07 & 88.1 & 0.64 & 42.3 & 0.99 & 88.5 & 0.42 \\
\hline Soluble protein & 6.35 & 0.07 & 2.25 & 0.07 & 4.20 & 0.57 & 7.05 & 0.07 \\
\hline $\mathrm{ADICP}^{2}$ & 1.16 & 1.12 & 1.03 & 0.15 & 0.48 & 0.01 & 0.72 & 0.40 \\
\hline $\mathrm{NDICP}^{3}$ & 3.70 & 0.07 & 3.11 & 0.71 & 0.66 & 0.08 & 1.74 & 0.49 \\
\hline Lignin & 8.70 & 0.28 & 7.17 & 0.89 & 2.73 & 0.05 & 2.92 & 0.25 \\
\hline $\mathrm{NFC}^{4}$ & 26.4 & 0.14 & 19.0 & 1.06 & 55.9 & 0.57 & 44.0 & 0.35 \\
\hline Starch & 0.95 & 0.49 & 0.25 & 0.07 & 42.4 & 0.57 & 27.5 & 1.56 \\
\hline Sugar & 3.15 & 0.07 & 6.20 & 0.71 & 1.00 & 0.00 & 5.50 & 0.42 \\
\hline Crude fat & 1.10 & 0.28 & 1.90 & 0.02 & 3.14 & 0.36 & 6.19 & 0.09 \\
\hline Ash & 10.5 & 0.19 & 10.0 & 0.43 & 4.19 & 0.28 & 10.2 & 0.25 \\
\hline $\mathrm{Ca}$ & 1.17 & 0.04 & 0.44 & 0.06 & 0.20 & 0.01 & 2.35 & 0.09 \\
\hline $\mathrm{Cl}$ & 0.11 & 0.01 & 0.30 & 0.04 & 0.15 & 0.01 & 0.40 & 0.02 \\
\hline $\mathrm{Fe}, \mathrm{mg} / \mathrm{kg}$ & 279.0 & 43.8 & 213.0 & 21.2 & 160.5 & 43.1 & 474.5 & 10.6 \\
\hline $\mathrm{Zn}, \mathrm{mg} / \mathrm{kg}$ & 24.0 & 0.00 & 18.0 & 0.00 & 24.5 & 0.71 & 230.0 & 76.4 \\
\hline $\mathrm{Cu}, \mathrm{mg} / \mathrm{kg}$ & 9.0 & 0.00 & 7.50 & 0.71 & 7.00 & 0.00 & 38.0 & 0.00 \\
\hline $\mathrm{Mn}, \mathrm{mg} / \mathrm{kg}$ & 34.5 & 2.12 & 49.0 & 0.00 & 22.0 & 1.41 & 139.5 & 4.95 \\
\hline
\end{tabular}

${ }^{1}$ Mean and SD were calculated based on samples of each feedstuff collected during each period and estimated by a commercial feed testing laboratory (Cumberland Valley Analytical Services, Hagerstown, MD).

${ }^{2}$ Acid detergent insoluble CP.

${ }^{3}$ Neutral detergent insoluble CP.

${ }^{4}$ Calculated as $100-(\% \mathrm{NDF}+\% \mathrm{CP}+\%$ fat $+\%$ ash $)$.

boil the urine, 2 thawed $250-\mathrm{mL}$ bottles of urine were poured into a $600-\mathrm{mL}$ beaker. Fourteen urine-filled beakers were placed into a boiling water bath (Ankom Technology, Macedon, NY) underneath a hood. The water bath was turned on in the morning and off in the afternoon, for approximately $6 \mathrm{~h}$ each $\mathrm{d}$, to reduce the chance of the sample being overheated and burned. After water was boiled away, the remaining paste was then composited by cow and period. The urine paste was then lyophilized (VirTis Freezemobile 25ES, SP Scientific, Gardiner, NY) and analyzed. Once lyophilized, sample particle size was reduced using mortar and pestle and then used for analysis. Urine samples were analyzed at the University of Nebraska-Lincoln for laboratory-corrected $\mathrm{DM}\left(100^{\circ} \mathrm{C}\right.$ oven for $\left.24 \mathrm{~h}\right), \mathrm{N}$, and gross energy (GE) using a bomb calorimeter $(6400$ Calorimeter, Parr) as described previously.

Milk production was measured daily, and milk samples were collected during both milking times for 4 consecutive days or d 11 to 14 of the entire period. Two tubes were collected for each milking $(100 \mathrm{~mL})$; one $50-\mathrm{mL}$ conical tube was frozen at $-20^{\circ} \mathrm{C}$, and one $50-\mathrm{mL}$ sampling tube was preserved using 2-bromo2-nitropropane-1,3 diol. Samples were sent to Heart of America DHIA (Kansas City, MO) and analyzed for fat, protein, lactose, SNF, MUN, and SCC using a Bentley FTS/FCM Infrared Analyzer (Bentley Instruments, Chaska, MN). The conical tube was lyophilized to determine DM and then composited by cow and period for nutrient analysis. Milk samples were analyzed at the University of Nebraska-Lincoln for laboratory-corrected DM, N, and GE. To determine the DM content of individual feed ingredients, TMR, refusals, feces, and urine samples were dried at $60^{\circ} \mathrm{C}$ in a forced-air oven for $48 \mathrm{~h}$ and then composited by treatment or cow and period. Feed ingredients, refusals, and feces were ground as previously described and used for laboratory-corrected DM and GE.

Heat production (HP) was determined through the headbox-style indirect calorimeters described by Foth et al. (2015) and Freetly et al. (2006). Before collection, headboxes were used to test the rate of recovery of gas by burning $100 \%$ ethyl alcohol in the sealed headbox and comparing this measure with calculated gas concentrations. These calculations were based on the weight of alcohol burned and a measured volume of gas sample. Before the start of the experiment, 5 gas recoveries were conducted to verify proper function of the system. Recovery rates of oxygen $\left(\mathrm{O}_{2}\right)$ and carbon dioxide $\left(\mathrm{CO}_{2}\right)$ averaged $101.0 \pm 0.04$ and 100.8 
$\pm 0.04 \%$, respectively. For each cow, $\mathrm{O}_{2}$ consumption and $\mathrm{CO}_{2}$ and $\mathrm{CH}_{4}$ production were measured during a collection period of a single 23-h interval. A single day was used because feed intake for cattle was stable, with cattle consuming $95 \%$ of their ad libitum intake. Four indirect calorimeters were used, and measures were taken on all cattle in 3 groups of 4 on the last $3 \mathrm{~d}$ of each period. The design of the headboxes allowed for feed to be placed in the bottom of the box, and ad libitum access to water was available for the cows from a water bowl placed inside the headbox. Within the headbox, temperature and dew point were recorded every minute for a 23-h interval using a probe (model TRH-100, Pace Scientific Inc., Moorseville, NC) that was connected to a data logger (model XR440, Pace Scientific Inc.). Fifteen minutes before the start of the collection, the doors were closed and the motor was turned on to allow for several air turnovers before gases were collected. Line pressure was measured using a manometer (item no. 1221-8, United Instruments, Westbury, NY). Barometric pressure of the room was also recorded using a barometer (Chaney Instruments Co., Lake Geneva, WI) and uncorrected for sea level. Total volume of gas that passed through the headbox during each run was measured using a dry gas meter (model AL425, American Meter). From the headbox, continuous amounts of outgoing and incoming air were diverted to 2 different collection bags $(61 \times 61 \mathrm{~cm}$ LAM-JAPCON-NSE, $44 \mathrm{~L}$; PMC, Oak Park, IL) using glass tube rotameters (model 1350E Sho-Rate 50, Brooks Instruments, Hatfield, PA). Collection bags with gas samples inside were analyzed for $\mathrm{O}_{2}, \mathrm{CO}_{2}$, and $\mathrm{CH}_{4}$ at the University of NebraskaLincoln laboratory according to Nienaber and Maddy (1985). The gas analyzer (Emerson X-stream 3-channel analyzer, Rosemount Analytical, Emerson Electric Co., St. Louis, MO) was a paramagnetic $\mathrm{O}_{2}$ analyzer and a dual channel $\mathrm{CO}_{2}$ and $\mathrm{CH}_{4}$ infrared analyzer and was calibrated with standards containing gases of concentration similar to those collected from the headbox. For diurnal measurements, continuous amounts of outgoing and incoming air were pumped through a sample pump station (Universal Analyzers Inc., Carson City, NV) from the headbox to the gas analyzer and were analyzed once per hour at the University of NebraskaLincoln according to Nienaber and Maddy (1985). Heat production was estimated using $\mathrm{O}_{2}$ consumption, $\mathrm{CO}_{2}$ and $\mathrm{CH}_{4}$ production, and urinary $\mathrm{N}$ excretion according to Brouwer (1965; Equation 1). The gaseous products were reported in liters, and the mass of urinary $\mathrm{N}$ was reported in grams. Respiratory quotient was calculated using the ratio of $\mathrm{CO}_{2}$ produced to the $\mathrm{O}_{2}$ consumed and was not corrected for $\mathrm{N}$. Volume of $\mathrm{CH}_{4}$ produced was multiplied by a constant of $9.45 \mathrm{kcal} / \mathrm{L}$ to estimate the amount of energy formed from the gaseous prod- ucts. Energy balance was calculated for each cow and adjusted for excess $\mathrm{N}$ intake according to Freetly et al. (2006) using Equations 2, 3, 4, and 5:

$$
\begin{gathered}
\mathrm{HP}(\mathrm{Mcal} / \mathrm{d})=3.866 \times \mathrm{O}_{2}(\mathrm{~L})+1.200 \\
\times \mathrm{CO}_{2}(\mathrm{~L})-0.518 \times \mathrm{CH}_{4}(\mathrm{~L})-1.431 \times \mathrm{N}(\mathrm{g}),[1] \\
\mathrm{ME}(\mathrm{Mcal} / \mathrm{d})=\mathrm{GE} \text { intake }(\mathrm{Mcal} / \mathrm{d}) \\
- \text { fecal energy }(\mathrm{Mcal} / \mathrm{d})-\text { urinary energy }(\mathrm{Mcal} / \mathrm{d}) \\
- \text { methane energy }(\mathrm{Mcal} / \mathrm{d}), \\
\text { Net energy balance }(\mathrm{Mcal} / \mathrm{d})=\mathrm{ME}-\mathrm{HP}, \\
\text { Tissue energy }(\mathrm{Mcal} / \mathrm{d})=\mathrm{recovered} \text { energy } \\
- \text { milk energy }(\mathrm{Mcal} / \mathrm{d}), \\
\text { Tissue energy in protein }(\mathrm{g} / \mathrm{d})= \\
\mathrm{N} \text { balance }(\mathrm{g} / \mathrm{d}) \times(5.88 \mathrm{~kg} \text { of protein } / \mathrm{kg} \text { of } \mathrm{N}) \\
\times(5.7 \mathrm{Mcal} / \mathrm{kg} \text { of protein }) / 1,000 .
\end{gathered}
$$

Metabolizable energy for maintenance was calculated using regression of net energy balance (per kilogram of MBW) and intake of ME (per kilocalorie of MBW) and is the ME at zero net energy balance, as listed in Figure 1. Tissue energy in protein describes the energy used for tissue protein synthesis (Equation 5). Standing behavior was measured over $4 \mathrm{~d}$ encompassing 24 -h periods starting on the first day of total collections by having a technician visually observe whether cattle were standing every $10 \mathrm{~min}$. It was assumed that the incidence of standing lasted the entire 10-min interval; thus, total minutes of standing was a sum of each observation for the entire day. Standing behavior was measured to better understand the effects of temporarily modifying the cattle's environment while in the headbox.

\section{Statistical Analysis}

Production, energy metabolism, and $\mathrm{N}$ balance data were analyzed using the MIXED procedure of SAS (SAS Institute Inc., Cary, NC). Treatment and period were modeled as fixed effects, whereas cow was modeled as a random effect. The LSMEANS option was used to generate least squares means of treatments listed in this study. Diurnal variation was analyzed as repeated measures by using the autoregressive repeated covariance structure in SAS (SAS Institute Inc., Cary, NC). The effects of period, treatment, hour, and treatment $x$ hour interaction were considered as fixed, and cow was considered as a random effect. Standing behavior 


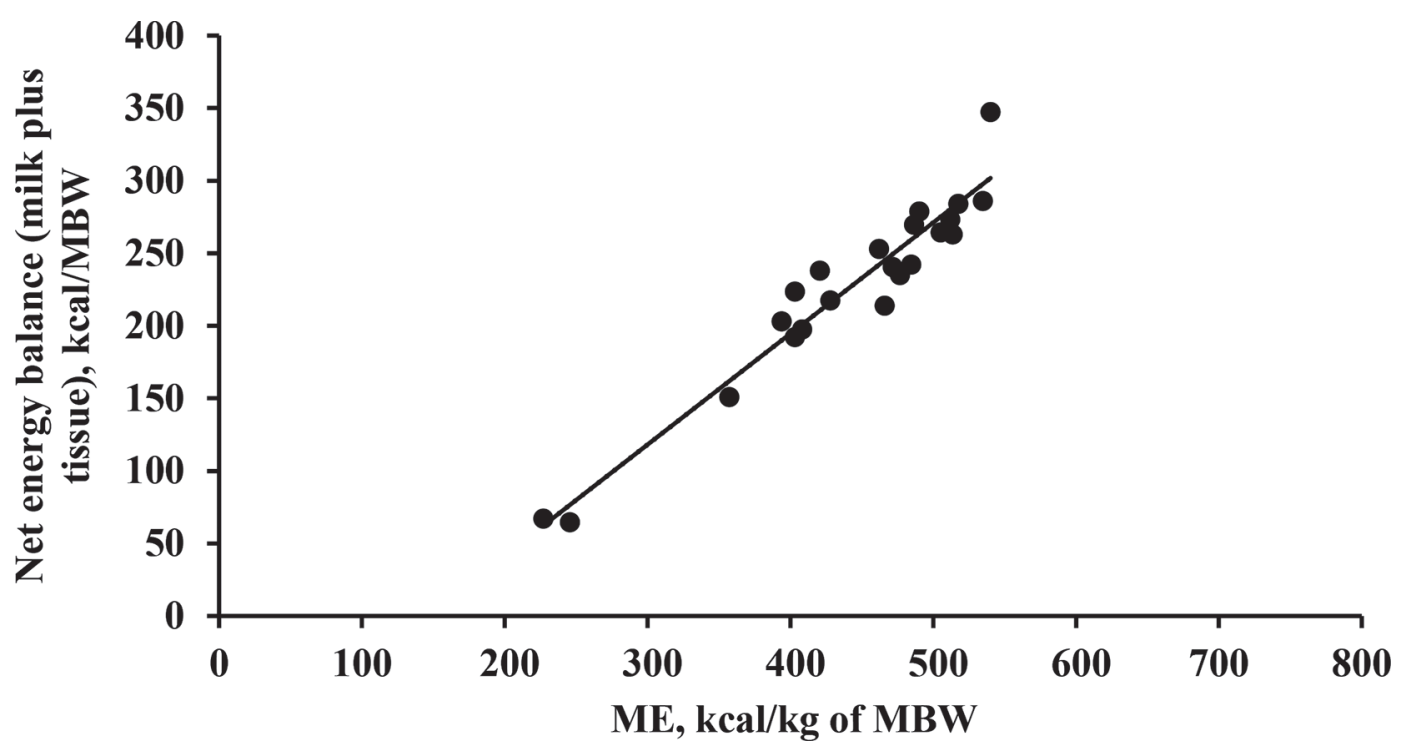

Figure 1. Regression of net energy balance (milk plus tissue) on ME intake in kilocalories per kilogram of metabolic BW (MBW; $=0.7648 \mathrm{x}$ -111.31 ; mean squared error $\left.=340.3 ; \mathrm{R}^{2}=0.93\right)$. Net energy balance $=0$ at $146 \mathrm{kcal} / \mathrm{MBW}$, and efficiency of converting ME to net energy balance (ME - heat production) is $76 \%$.

was analyzed using the MIXED procedure of SAS. Treatment, period, and location were modeled as fixed effects, whereas cow was modeled as a random effect. Significance was declared at $P \leq 0.05$ and trends were declared at $0.05<P \leq 0.10$.

\section{RESULTS AND DISCUSSION}

\section{Diet Composition}

The goal of the current study was to test the effects of feeding frequency on diurnal $\mathrm{CH}_{4}$ production and energy use in late-lactation cattle. As such, all cows received the same diet; chemical composition of these diets and individual feed ingredients are listed in Tables 1 and 2. Crude protein was approximately $18.5 \pm 0.25 \%$, and the concentration of GE was $4.42 \pm 0.09 \mathrm{Mcal} / \mathrm{kg}$ of DM. Particle size distribution was measured (Table 3) and was generally similar to the recommendations

Table 3. Particle size ${ }^{1}$ distribution of TMR (as-fed basis) fed to Jersey cows in late lactation

\begin{tabular}{lcc}
\hline & \multicolumn{2}{c}{ Experimental diet } \\
\cline { 2 - 3 } Particle size, \% & Mean & SD \\
\hline$>19.0 \mathrm{~mm}$ & 4.81 & 1.28 \\
$19.0-8.0 \mathrm{~mm}$ & 25.2 & 1.87 \\
$8.0-1.18 \mathrm{~mm}$ & 50.9 & 2.92 \\
$<1.18 \mathrm{~mm}$ & 18.9 & 2.32 \\
\hline
\end{tabular}

${ }^{1}$ Determined using the Penn State Particle Separator on a wet basis (Heinrichs and Kononoff, 2002). for particle size for dairy cattle (Heinrichs and Kononoff, 2002; Table 3). Period lengths were short and only $14 \mathrm{~d}$ in duration; however, our test was specific to the frequency of feed offerings and not diet changes. Thus, we suggest that given that no changes in formulations were conducted, the period was of sufficient duration to determine the effect of feeding frequency on ruminal $\mathrm{CH}_{4}$ production.

\section{DMI, Milk Production, and Composition}

Increasing feeding frequency in cattle may stimulate appetite and, as a result, increase DMI. Campbell and Merilan (1960) fed lactating Guernsey cattle either 2 or 4 times daily and observed a $1.5 \mathrm{~kg} / \mathrm{d}$ increase in daily DMI with an accompanying increase in milk yield with 4 times daily feedings. Similarly, Crompton et al. (2011) fed lactating Holstein-Friesian cattle either 1 or 2 times daily and observed a 1.2-kg increase in DMI and a $1.4-\mathrm{kg}$ increase in milk production with increased feeding frequency. In the current study, we speculated that increased feeding frequency would increase DMI and rumen fermentation. In the current study, DMI did not differ $(P=0.292)$ by increasing feeding frequency, averaging $16.9 \pm 0.88 \mathrm{~kg} / \mathrm{d}$ (Table 4); however, cattle were restricted to $95 \%$ of ad libitum intake in the current study. Visual appraisal of refusals before the second feeding suggested minimal weighback, although weight of refusals was not measured, and it is possible that large amounts of refusals may minimize the effects of increasing feeding frequencies. However, there was 
a trend for milk yield to decrease $(P=0.097)$ with increasing feeding frequency $(21.2$ vs. $20.4 \pm 1.59 \mathrm{~kg} / \mathrm{d}$ for once- vs. twice-daily feeding, respectively). This observation was not expected because it is generally believed that increased feed frequency would result in increased feed intake and, as a consequence, increased milk yield (Hart et al., 2014); however, such responses are not always observed (Nocek and Braund, 1985). Increasing feeding frequency has been observed to increase the percentage of milk fat (Nocek and Braund, 1985), which has been attributed to the stabilization of the $\mathrm{pH}$ in the rumen. In the current study, milk fat percentage did not differ $(P=0.966)$ by feeding frequency, averaging $6.18 \pm 0.20 \%$. In the current study, milk fat yield also tended $(P=0.097)$ to decrease with increasing feeding frequency $(1.30$ vs. $1.26 \pm 0.10 \mathrm{~kg} / \mathrm{d}$ for once- and twice-daily feeding, respectively). The decreased milk fat yield is likely due to decreased milk yield. However, Macmillan et al. (2017) fed cattle 1 or 3 times daily and observed increased milk fat yield, which they suggested may be due to a greater rumen $\mathrm{pH}$. Milk protein percentage did not differ $(P=0.717)$, averaging $3.98 \pm 0.08 \%$. In the current study, milk protein yield increased $(P=0.040)$ when increasing feeding frequency $(0.84$ and $0.81 \pm 0.01 \mathrm{~kg} / \mathrm{d}$ for once- and twice-daily feeding, respectively).

\section{Gas Consumption and Production}

Heat production is a loss of energy that was indirectly measured in the current experiment and was calculated based on the volume of $\mathrm{O}_{2}$ consumed and $\mathrm{CO}_{2}$ and $\mathrm{CH}_{4}$ produced (Brouwer, 1965). Heat production increases with increases in DMI (Purwanto et al., 1990). In the current study, $\mathrm{O}_{2}$ consumption was not affected $(P=$ 0.218 ) by feeding frequency, averaging $4,411.3 \pm 181.9$ $\mathrm{L} / \mathrm{d}$ (Table 5). Similarly, $\mathrm{CO}_{2}$ production was not affected $(P=0.161)$ by feeding frequency, averaging $4,673.9 \pm 221.0 \mathrm{~L} / \mathrm{d}$. Typically, daily $\mathrm{CH}_{4}$ production ranges from 500 to $600 \mathrm{~L} / \mathrm{d}$ for high-producing Holstein cattle (Beauchemin et al., 2008; Chase, 2014). In the current study, total $\mathrm{CH}_{4}$ production was not affected $(P=0.793)$ by feeding frequency and, as expected using Jersey cows in late lactation, was lower than for Holstein cows, averaging $402.1 \pm 20.8 \mathrm{~L} / \mathrm{d}$. Methane produced per unit of milk yield was not different $(P$ $=0.233$ ) between feeding frequency, averaging $20.5 \pm$ $1.81 \mathrm{~L} / \mathrm{kg}$. Similar to the current study, Crompton et al. (2011) studied mid-lactation Holstein-Friesian cattle being fed either 1 or 2 times daily and observed $\mathrm{CH}_{4}$ production per unit of milk produced to be $20.9 \mathrm{~L} / \mathrm{kg}$. In the current study, $\mathrm{CH}_{4}$ production per unit of DMI was not different $(P=0.543)$ by increasing feeding frequency, with a mean of $23.8 \pm 1.21 \mathrm{~L} / \mathrm{kg}$. Crompton et
Table 4. Dry matter intake, milk production and composition, BW, BCS, and water intake of late-lactation Jersey cows fed once $(1 \times)$ or twice $(2 \times)$ per day

\begin{tabular}{|c|c|c|c|c|}
\hline \multirow[b]{2}{*}{ Item } & \multicolumn{2}{|c|}{ Feeding frequency } & \multirow[b]{2}{*}{$\mathrm{SEM}^{1}$} & \multirow[b]{2}{*}{$P$-value } \\
\hline & $1 \times$ & $2 \times$ & & \\
\hline DMI, $\mathrm{kg} / \mathrm{d}$ & 17.1 & 16.7 & 0.88 & 0.292 \\
\hline Milk yield, $\mathrm{kg} / \mathrm{d}$ & 21.2 & 20.4 & 1.59 & 0.097 \\
\hline $\mathrm{ECM},{ }^{2} \mathrm{~kg} / \mathrm{d}$ & 29.9 & 28.8 & 2.21 & 0.063 \\
\hline Fat, $\%$ & 6.18 & 6.18 & 0.20 & 0.966 \\
\hline Fat yield, $\mathrm{kg} / \mathrm{d}$ & 1.30 & 1.26 & 0.10 & 0.097 \\
\hline $\mathrm{FCM}, \mathrm{kg} / \mathrm{d}$ & 30.3 & 29.3 & 2.24 & 0.085 \\
\hline Protein, \% & 3.98 & 3.97 & 0.08 & 0.717 \\
\hline Protein yield, $\mathrm{kg} / \mathrm{d}$ & 0.84 & 0.81 & 0.01 & 0.040 \\
\hline Lactose, \% & 4.55 & 4.53 & 0.05 & 0.439 \\
\hline MUN, mg/dL & 20.9 & 20.1 & 0.85 & 0.056 \\
\hline $\mathrm{SCC}$, cells $/ \mathrm{mL}$ & 129.5 & 106.3 & 35.1 & 0.477 \\
\hline Free water intake, $\mathrm{L} / \mathrm{d}$ & 83.8 & 75.7 & 5.67 & 0.026 \\
\hline $\mathrm{BW}, \mathrm{kg}$ & 483.0 & 480.1 & 12.2 & 0.223 \\
\hline $\mathrm{BCS}^{3}$ & 3.37 & 3.43 & 0.11 & 0.148 \\
\hline
\end{tabular}

${ }^{1}$ Lowest SE of treatment means is listed.

${ }^{2}$ Calculated as $0.327 \times$ milk yield $(\mathrm{kg})+7.2 \times$ protein $(\mathrm{kg})$ adjusted for $3.5 \%$ fat and $3.2 \%$ total protein (DRMS, 2014).

${ }^{3} 1$-to-5 scale according to Wildman et al. (1982).

al. (2011) observed $\mathrm{CH}_{4}$ production per unit of DMI to be $30.1 \mathrm{~L} / \mathrm{kg}$ in lactating dairy cattle in mid lactation. Additionally, HP per unit of MBW did not differ $(P=$ 0.232 ) by feeding frequency, with a mean of $215.5 \pm$ $8.19 \mathrm{kcal} / \mathrm{kg}$ of MBW.

\section{Diurnal $\mathrm{CH}_{4}$ Production}

In cattle, $\mathrm{CH}_{4}$ production is episodic (Hegarty, 2013) and can vary by up to 5-fold throughout the day (Crompton et al., 2011). Feeding practices, such as

Table 5. Methane production, methane efficiencies, and heat production for late-lactation Jersey cows fed once $(1 \times)$ or twice $(2 \times)$ per day

\begin{tabular}{lcccc}
\hline & \multicolumn{2}{c}{$\begin{array}{c}\text { Feeding } \\
\text { frequency }\end{array}$} & & \\
\cline { 2 - 3 } & $1 \times$ & $2 \times$ & SEM $^{1}$ & $P$-value \\
\cline { 2 - 3 } Item & $4,500.6$ & $4,321.9$ & 181.9 & 0.218 \\
\hline $\mathrm{O}_{2}$ consumption, L/d & $4,803.3$ & $4,544.4$ & 221.0 & 0.161 \\
$\mathrm{CO}_{2}$ production, L/d & 399.6 & 404.5 & 20.8 & 0.793 \\
$\mathrm{CH}_{4}$ production, L/d & 19.9 & 21.0 & 1.81 & 0.233 \\
$\mathrm{CH}_{4} /$ milk yield, L/kg & 14.1 & 14.8 & 1.20 & 0.212 \\
$\mathrm{CH}_{4} / \mathrm{ECM}, \mathrm{L} / \mathrm{kg}$ & 1.06 & 1.05 & 0.01 & 0.238 \\
$\mathrm{RQ}^{2}{ }^{2} \mathrm{~L} / \mathrm{L}$ & 23.4 & 24.1 & 1.21 & 0.543 \\
$\mathrm{CH}_{4} / \mathrm{DMI}, \mathrm{L} / \mathrm{kg}$ & 22.6 & 21.6 & 0.95 & 0.212 \\
$\mathrm{HP},{ }^{3} \mathrm{Mcal} / \mathrm{d}$ & 219.7 & 211.3 & 8.19 & 0.232 \\
$\mathrm{HP}, \mathrm{kcal} / \mathrm{BW}{ }^{0.75}$ & & & & \\
\hline
\end{tabular}

${ }^{1}$ Lowest $\mathrm{SE}$ of treatment means is listed.

${ }^{2} \mathrm{RQ}=$ respiratory quotient $\left(\mathrm{CO}_{2}\right.$ production $/ \mathrm{O}_{2}$ consumption $)$.

${ }^{3} \mathrm{HP}=$ heat production, calculated with the Brouwer (1965) equation from $\mathrm{O}_{2}$ consumption $(\mathrm{L}), \mathrm{CO}_{2}$ production $(\mathrm{L})$, methane production $(\mathrm{L})$, and urine $\mathrm{N}(\mathrm{g}): \mathrm{HP}=3.866 \times \mathrm{O}_{2}+1.200 \times \mathrm{CO}_{2}-0.518 \times$ $\mathrm{CH}_{4}-1.431 \times \mathrm{N}$. 


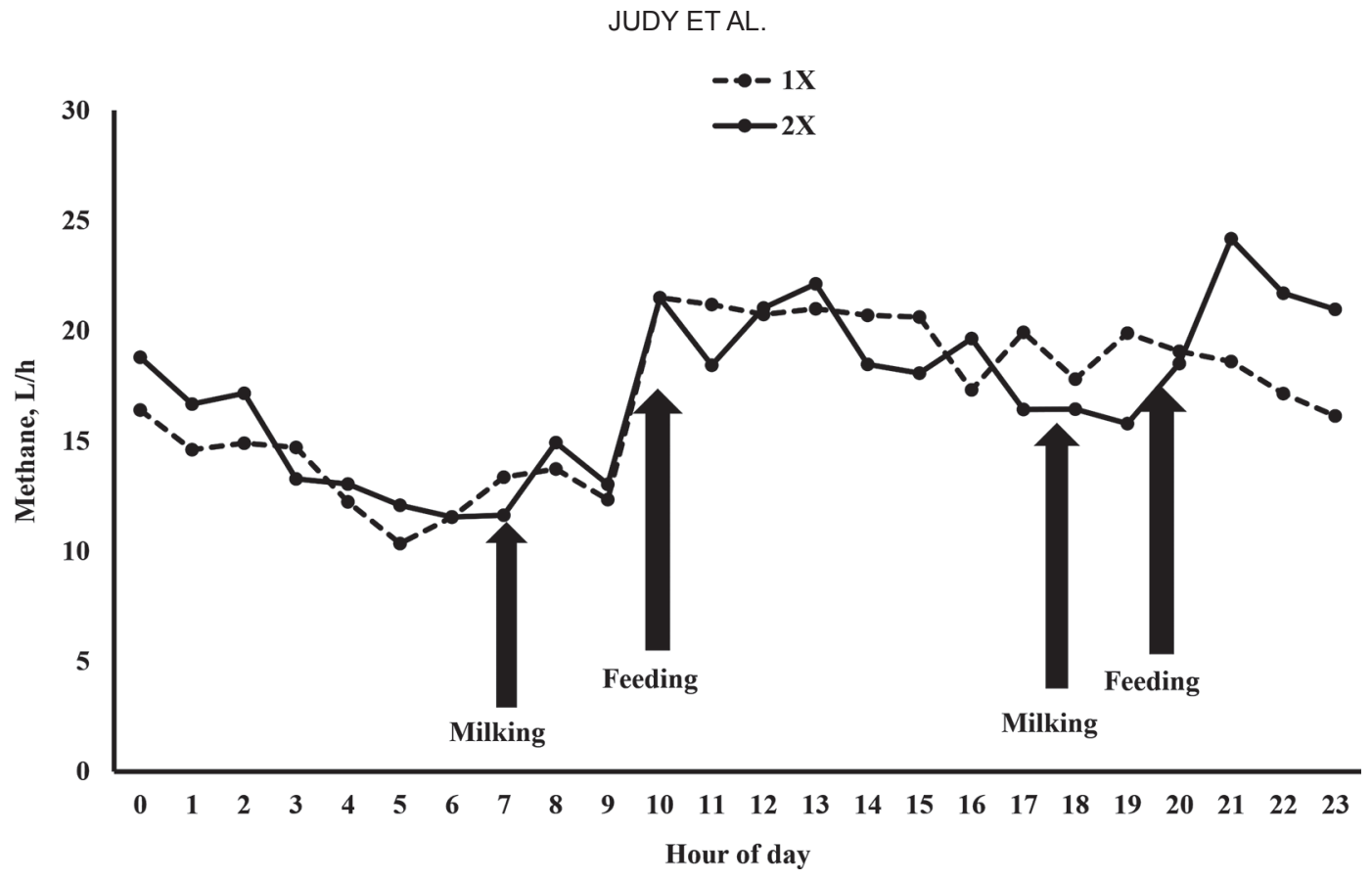

Figure 2. Hourly methane production from late-lactation dairy cows fed once daily $(1 \times)$ at $1000 \mathrm{~h}$ or twice daily $(2 \times)$ at 1000 and $2000 \mathrm{~h}$. Overall methane production per hour was not different $(P=0.445)$, with a mean of $17.1 \pm 0.74 \mathrm{~L} / \mathrm{h}$. Hour postfeeding affected $(P<0.001)$ methane production, and there was a trend for treatment $\times$ hour $(P=0.084)$. Hours 21 to 23 had greater $(P=0.014, P<0.001$, and $P=0.004$ for $\mathrm{h} 21,22$, and 23 , respectively) methane production for cows fed twice daily compared with those fed once daily, corresponding to the second feeding occurring $10 \mathrm{~h}$ after a.m. feeding.

feeding frequency, have been demonstrated to influence fermentation patterns and resulting gas production in dairy cattle (Brask et al., 2015). In the current study, we fed cattle once in the morning and then again $10 \mathrm{~h}$ later, after the second milking, for the twice-daily feeding. In the current study, the rate of $\mathrm{CH}_{4}$ production per hour overall was not different $(P=0.445)$, with a mean of $17.1 \pm 0.74 \mathrm{~L} / \mathrm{h}$ (Figure 2 ). A major objective of this study was to characterize diurnal $\mathrm{CH}_{4}$ production, and we hypothesized that $\mathrm{CH}_{4}$ production would increase after each feeding. Indeed, $\mathrm{CH}_{4}$ production was affected $(P<0.001)$ by time of day. A trend was also observed for the interaction of feeding frequency and time $(P=0.084)$. Although total $\mathrm{CH}_{4}$ production was not different, when feeding twice a day the concentration of $\mathrm{CH}_{4}$ was higher at 2100 to $2300 \mathrm{~h}$ compared with feeding once a day, which corresponds to the second feeding, which occurred at $2000 \mathrm{~h}(P=0.014, P<$ 0.001 , and $P=0.004$ for h 21,22 , and 23 , respectively). Thus, we conclude that the greater $\mathrm{CH}_{4}$ production at h 21,22 , and 23 for cows fed twice daily compared with once daily corresponded with the second feeding, which occurred $10 \mathrm{~h}$ after morning feeding. Interestingly, $\mathrm{CH}_{4}$ increased approximately $2 \mathrm{~h}$ postmilking for each milking for cattle fed twice daily and may have resulted from increased physical activity induced by milking procedures and activity. Previous research has observed increased $\mathrm{CH}_{4}$ production corresponding to feeding (Crompton et al., 2011). In the current study, peak $\mathrm{CH}_{4}$ production after the second feeding was greater than the initial peak following the morning feeding. Similarly, Crompton et al. (2011) observed a larger peak in $\mathrm{CH}_{4}$ production after the second feeding than the initial feeding. Although the observations of the current study are not new, they suggest that frequent samplings or measurements are required for $\mathrm{CH}_{4}$ production to be estimated accurately.

\section{Standing and Headbox Behavior}

Cattle have an inherent need to rest or lie down during the day. Lying down potentially increases milk synthesis by increasing blood flow to the udder and increasing rumination (Grant, 2009). Hence, increased standing time may negatively affect milk yield in lactating dairy cattle. With cattle fed twice daily, DeVries and von Keyserlingk (2005) observed lactating dairy cattle to stand approximately $11.7 \mathrm{~h} / \mathrm{d}$. In the current study, we tested the effect of feeding frequency on standing behavior for cattle either inside or outside the headbox (data not shown). This test was conducted so we could gain an understanding of estimates generated with our apparatus used to indirectly measure HP. Overall, standing behavior was not affected $(P=$ 
0.773 ) by feeding frequency, averaging $11.5 \pm 0.63 \mathrm{~h} / \mathrm{d}$; however, daily standing time was observed to be more than $2 \mathrm{~h}$ greater $(P<0.001)$ for cattle placed in the headbox (12.7 vs. $10.1 \mathrm{~h} / \mathrm{d}$ for inside vs. outside the headbox, respectively; data not shown). Grant (2009) observed a $1.5-\mathrm{kg}$ increase in milk yield for every additional hour cattle were lying down to rest. This is in part due to the fact that increased time standing may increase energy needs and may divert energy away from productive purposes. Practically, our results may suggest that observations collected in this system may modestly overestimate energy used by the animal to support additional time standing, and further research is warranted to determine the extent of this bias. This observation should not be taken to conclude that resting time was inadequate, as lying time was still within the recommended time of 12 to $14 \mathrm{~h} / \mathrm{d}$ (Kammel et al., 2017). Nonetheless, because our animals were restricted in our laboratory environment, these conditions were different than a commercial environment. Dry matter intake did not differ $(P=0.97)$ when cattle were either in or out of the headbox $(16.9$ vs. $17.0 \pm 0.37 \mathrm{~kg} / \mathrm{d}$ for in vs. out, respectively). Similarly, milk yield did not differ $(P=0.12)$ when cattle were either in or out of the headbox (21.2 vs. $20.6 \pm 0.95 \mathrm{~kg} / \mathrm{d}$ for in vs. out, respectively). Cattle had extensive acclimation to the headboxes, which reduced the potential negative effects of altering their environment.

\section{Energy Partitioning and Nutrient Digestibility}

Total Energy Intake. The energy content of feed consumed plays a crucial role in the formulation of lactating dairy cattle diets to adequately meet the animals' nutrient requirements (Weiss, 1993). Typically, feed energy is presented as energy available per unit of DMI, which is broken down to GE, digestible energy (DE), ME, and balance (milk plus tissue). Gross energy intake did not differ $(P=0.375)$ by feeding frequency, averaging $76.1 \pm 4.43 \mathrm{Mcal} / \mathrm{d}$ (Table 6). Similarly, DE and ME intake did not differ $(P \geq 0.626)$ by feeding frequency $(52.6 \pm 3.02$ and $45.5 \pm 2.77$ $\mathrm{Mcal} / \mathrm{d}$, respectively). Last, energy balance (milk plus tissue) did not differ $(P=0.702)$ by feeding frequency, averaging $23.4 \pm 2.13 \mathrm{Mcal} / \mathrm{d}$. Gross energy concentration per kilogram of DM did not differ $(P=0.234)$ by feeding frequency, averaging $4.41 \pm 0.01 \mathrm{Mcal} / \mathrm{kg}$ of DM. Similarly, DE and ME intake per kilogram of DM did not differ $(P \geq 0.926)$ by frequency of feeding, averaging $3.05 \pm 0.03$ and $2.63 \pm 0.03 \mathrm{Mcal} / \mathrm{kg}$ of DM, respectively. The resulting ME:DE averaged 0.865 and is similar to that of Cammell et al. (2000) and Reynolds et al. (2014). Energy balance (milk plus tissue) of lacta- tion per kilogram of DMI did not differ $(P=0.566)$ by frequency of feeding, averaging $1.32 \pm 0.08 \mathrm{Mcal} / \mathrm{kg}$ of DM.

Energy Loss and Gains. In late-lactation dairy cattle, energy lost from feces, heat, urine, and $\mathrm{CH}_{4}$ is approximately 28, 42, 5, and 5\% of GE, respectively (Flatt et al., 1967). In the current study, fecal energy as a percentage of GE did not differ $(P=0.865)$ by feeding frequency, with a mean of $30.8 \pm 0.63 \%$, which is higher than historical data (Table 6). Urine energy in the current study did not differ $(P=0.722)$ by feeding frequency, with a mean of $4.44 \pm 0.01 \%$. Methane and heat energy did not differ $(P \geq 0.212)$ by feeding frequency, with a mean of $5.1 \pm 0.26 \%$ and $29.7 \pm 1.40 \%$, respectively. Heat production in the current study was lower than in previous research, which shows HP to be approximately $33 \%$ of GE (Tine et al., 2001); however, this may be the result of the different diets fed. In the current study, net energy balance (milk plus tissue) did not differ $(P=0.702)$ by feeding frequency, averaging $23.4 \pm 2.13 \mathrm{Mcal} / \mathrm{d}$. This was expected because HP and ME intake were similar between treatments. A trend was observed for milk energy to be greater $(P=0.061)$ for once-daily feeding compared with twice-daily feeding (20.9 vs. $19.7 \pm 1.53 \mathrm{Mcal} / \mathrm{d}$, respectively). The increased milk energy is the result of greater milk pro-

Table 6. Partitioning of energy for treatments for late-lactation Jersey cows fed once $(1 \times)$ or twice $(2 \times)$ per day

\begin{tabular}{|c|c|c|c|c|}
\hline \multirow[b]{2}{*}{ Item } & \multicolumn{2}{|c|}{$\begin{array}{l}\text { Feeding } \\
\text { frequency }\end{array}$} & \multirow[b]{2}{*}{$\mathrm{SEM}^{1}$} & \multirow[b]{2}{*}{$P$-value } \\
\hline & $1 \times$ & $2 \times$ & & \\
\hline $\begin{array}{l}\text { Gross energy (GE) intake, } \\
\text { Mcal/d }\end{array}$ & 76.6 & 75.6 & 4.43 & 0.375 \\
\hline Digestible energy (DE), Mcal/d & 52.9 & 52.3 & 3.02 & 0.626 \\
\hline $\mathrm{ME}, \mathrm{Mcal} / \mathrm{d}$ & 45.8 & 45.2 & 2.77 & 0.634 \\
\hline Balance, ${ }^{2} \mathrm{Mcal} / \mathrm{d}$ & 23.1 & 23.6 & 2.13 & 0.702 \\
\hline \multicolumn{5}{|l|}{ Component, Mcal/d } \\
\hline Feces & 23.7 & 23.3 & 1.53 & 0.484 \\
\hline Methane & 3.78 & 3.82 & 0.20 & 0.793 \\
\hline Urine & 2.67 & 2.56 & 0.10 & 0.794 \\
\hline Heat & 22.6 & 21.6 & 0.95 & 0.212 \\
\hline Balance $^{2}$ & 23.1 & 23.6 & 2.13 & 0.702 \\
\hline Milk & 20.9 & 19.7 & 1.53 & 0.061 \\
\hline Tissue energy & 2.22 & 3.84 & 1.30 & 0.211 \\
\hline Feces, $\%$ of $\mathrm{GE}$ & 30.7 & 30.9 & 0.63 & 0.865 \\
\hline Methane, $\%$ of GE & 5.03 & 5.16 & 0.26 & 0.568 \\
\hline Urine, $\%$ of GE & 4.46 & 4.41 & 0.17 & 0.722 \\
\hline DE, \% of GE & 69.3 & 69.2 & 0.63 & 0.865 \\
\hline $\mathrm{ME}, \%$ of $\mathrm{GE}$ & 59.8 & 59.6 & 0.64 & 0.794 \\
\hline GE, Mcal/kg of DM & 4.40 & 4.41 & 0.01 & 0.234 \\
\hline DE, Mcal/kg of DM & 3.05 & 3.05 & 0.03 & 0.977 \\
\hline ME, Mcal/kg of DM & 2.63 & 2.63 & 0.03 & 0.926 \\
\hline Balance, Mcal/kg of DM & 1.30 & 1.34 & 0.08 & 0.566 \\
\hline
\end{tabular}

${ }^{1}$ Lowest SE of treatment means is listed.

${ }^{2}$ Net energy balance (milk plus tissue). 
Table 7. Apparent digestibility of a common diet fed to late-lactation Jersey cows fed once $(1 \times)$ or twice $(2 \times)$ per day

\begin{tabular}{lcccc}
\hline & \multicolumn{2}{l}{ Feeding frequency } & & \\
\cline { 2 - 3 } Component, \% & $1 \times$ & $2 \times$ & SEM $^{1}$ & $P$-value \\
\hline DM & 70.2 & 70.2 & 0.52 & 0.967 \\
OM & 73.6 & 73.2 & 0.56 & 0.630 \\
CP & 75.0 & 74.7 & 0.71 & 0.676 \\
NDF & 44.2 & 43.4 & 1.23 & 0.600 \\
Starch & 93.2 & 93.8 & 0.46 & 0.305 \\
Ash & 18.5 & 23.2 & 4.52 & 0.313 \\
\hline
\end{tabular}

${ }^{1}$ Lowest SE of treatment means is listed.

duction in cattle fed once daily. Tissue energy did not differ $(P=0.211)$ by feeding frequency, averaging 3.03 $\pm 1.30 \mathrm{Mcal} / \mathrm{d}$. As cattle increase in DIM, milk production decreases, which in turn decreases the energy needed for lactation (Flatt et al., 1967). As a result, cattle can utilize available energy to build or deposit tissue in late lactation, as evidenced by the positive tissue balance.

Maintenance Energy and Efficiency of Energy Use for Lactation. Estimated maintenance energy is illustrated in Figure 1 and was determined through computation using regression of net energy balance per kilogram of MBW on ME per kilogram of MBW and then solving for ME intake when net energy balance equals zero (Foth et al., 2015). Metabolizable energy for maintenance was calculated to be $146 \mathrm{kcal} / \mathrm{kg}$ of MBW, with efficiency of converting ME to net energy balance (ME - HP) of 0.76 . This observation is identical to that reported by Freetly et al. (2006) and similar to previous estimates, which averaged near $143 \pm 26$ kcal/MBW for maintenance (Moe and Tyrrell, 1971; Vermorel et al., 1982; Birkelo et al., 2004; Xue et al., 2011; Foth et al., 2015). However, Yan et al. (1997) reported maintenance $\mathrm{ME}$ requirements to range between 146 and $179 \mathrm{kcal} / \mathrm{MBW}$. In a recent meta-analysis of historical energy balance data collected from the USDA Energy Metabolism Unit (Beltsville, MD) from 1963 to 1995 with Holstein cows, Moraes et al. (2015) reported an increase in maintenance requirement in more recent decades; this may be a function of increasing genetic merit of cattle. In the current study, late-lactation Jersey cattle were used and similar energy maintenance was observed. Overall, the maintenance energy requirements observed in the current study are within the range observed in the literature (Yan et al., 1997; Foth et al., 2015).

Nutrient Digestibility. Increasing the frequency of feeding from 2 to 4 times daily in lactating Guernsey cattle led to an observed increase in DM digestibility of approximately 8\% (Campbell and Merilan, 1960). Simi- larly, Shabi et al. (1999) fed lactating Holstein cattle either 2 or 4 times daily and observed an increase in OM and $\mathrm{CP}$ digestibility. Increased digestibility may lead to increased milk yield in lactating dairy cattle (Campbell and Merilan, 1960). However, in the current study, DM digestibility was not affected $(P=0.967)$ by increasing feeding frequency, averaging $70.2 \pm 0.52 \%$ (Table 7 ). Similarly, OM, CP, NDF, and starch digestibility were not affected $(P \geq 0.305)$ by feeding frequency, averaging $73.4 \pm 0.56 \%, 74.9 \pm 0.71 \%, 43.8 \pm 1.23 \%$, and 93.5 $\pm 0.46 \%$, respectively.

\section{Nitrogen Balance}

Tissue $\mathrm{N}$ balance is the $\mathrm{N}$ remaining after subtracting the $\mathrm{N}$ lost in the feces, urine, and milk from total $\mathrm{N}$ intake. Total $\mathrm{N}$ intake did not $\operatorname{differ}(P=0.132)$ by feeding frequency, with a mean of $512.8 \pm 29.0 \mathrm{~g} / \mathrm{d}$ (Table 8). Nitrogen intake has been observed to affect $\mathrm{N}$ excretion (Weiss et al., 2009). In the current study, N lost in the feces and urine was not affected $(P \geq 0.425)$ by feeding frequency, averaging $129.6 \pm 8.94$ and 216.9 $\pm 11.4 \mathrm{~g} / \mathrm{d}$ for feces and urine, respectively. This was expected because total $\mathrm{N}$ intake was similar between treatments. Milk $\mathrm{N}$ was not different $(P=0.367)$ by feeding frequency, averaging $149.2 \pm 11.8 \mathrm{~g} / \mathrm{d}$. Similarly, total $\mathrm{N}$ balance was not different $(P=0.911)$ by feeding frequency, averaging $17.3 \pm 13.0 \mathrm{~g} / \mathrm{d}$. A positive tissue $\mathrm{N}$ balance with the positive tissue energy balance observed suggests that the cattle in the current study were depositing body stores. In late lactation, cattle

Table 8. Partitioning of nitrogen by late-lactation Jersey cows fed a common diet either once $(1 \times)$ or twice $(2 \times)$ per day

\begin{tabular}{|c|c|c|c|c|}
\hline \multirow[b]{2}{*}{ Item } & \multicolumn{2}{|c|}{ Feeding frequency } & \multirow[b]{2}{*}{$\mathrm{SEM}^{1}$} & \multirow[b]{2}{*}{$P$-value } \\
\hline & $1 \times$ & $2 \times$ & & \\
\hline \multicolumn{5}{|l|}{ Mass, g/d } \\
\hline $\mathrm{N}$ intake & 519.5 & 506.0 & 29.0 & 0.132 \\
\hline Fecal N excretion & 130.6 & 128.5 & 8.94 & 0.425 \\
\hline Urine $\mathrm{N}$ excretion & 218.7 & 215.0 & 11.4 & 0.804 \\
\hline Total $\mathrm{N}$ excretion ${ }^{2}$ & 349.3 & 343.5 & 17.6 & 0.709 \\
\hline Milk N excretion & 151.9 & 146.4 & 11.8 & 0.367 \\
\hline Tissue $\mathrm{N}$ retention ${ }^{3}$ & 18.3 & 16.2 & 13.0 & 0.911 \\
\hline Tissue energy in protein & 0.61 & 0.54 & 0.44 & 0.911 \\
\hline \multicolumn{5}{|l|}{$\mathrm{N}, \%$ of intake } \\
\hline Fecal N & 25.0 & 25.3 & 0.71 & 0.676 \\
\hline Urine $\mathrm{N}$ & 43.1 & 43.6 & 2.68 & 0.848 \\
\hline Milk N & 29.1 & 28.6 & 1.41 & 0.615 \\
\hline $\mathrm{N}$ balance & 2.84 & 2.56 & 2.35 & 0.933 \\
\hline
\end{tabular}


replenish tissue reserves for the subsequent lactation, which likely occurred in the current study (NRC, 2001).

\section{CONCLUSIONS}

The present study demonstrated that increasing feeding frequency alters the diurnal pattern of $\mathrm{CH}_{4}$ production. Cattle fed a second time each day had an increase in $\mathrm{CH}_{4}$ production postfeeding; however, total $\mathrm{CH}_{4}$ production was unaffected by feeding frequency. Milk production and DMI were not affected by feeding frequency. Energy balance was not affected by feeding frequency. The derived ME for maintenance was 146 kcal of ME of MBW, and the efficiency of ME use to net energy balance was 0.76 .

\section{ACKNOWLEDGMENTS}

Partial funding for this project was provided by the Nebraska Environmental Trust (Lincoln, NE). Mention of trade names or commercial products in this article is solely for the purpose of providing specific information and does not imply recommendation or endorsement by the USDA.

\section{REFERENCES}

Aikman, P. C., C. K. Reynolds, and D. E. Beever. 2008. Diet digestibility, rate of passage, and eating and rumination behavior of Jersey and Holstein cows. J. Dairy Sci. 91:1103-1114.

AOAC International. 2000. Official Methods of Analysis. Vol. 1 and 2. 17th ed. AOAC International, Gaithersburg, MD.

AOAC International. 2006. Official Methods of Analysis. 18th ed. AOAC International, Gaithersburg, MD.

Bauman, D. E., and W. B. Currie. 1980. Partitioning of nutrients during pregnancy and lactation: A review of mechanisms involving homeostasis and homeorhesis. J. Dairy Sci. 63:1514-1529.

Beauchemin, K. A., M. Kreuzer, F. O'Mara, and T. A. McAllister. 2008. Nutritional management for enteric methane abatement: A review. Aust. J. Exp. Agric. 48:21-27.

Birkelo, C. P., M. J. Brouk, and D. J. Schingoethe. 2004. The energy content of wet corn distillers grains for lactating dairy cows. J. Dairy Sci. 87:1815-1819.

Boston, R. C., D. G. Fox, C. J. Sniffen, R. Janczewski, R. Munsen, and W. Chalupa. 2000. The conversion of a scientific model describing dairy cow nutrition and production to an industry tool: The CPM Dairy project. Pages 361-377 in Modelling Nutrient Utilization in Farm Animals. J. P. McNamara, J. France, and D. Beever, ed. CABI, Oxford, UK.

Brask, M., M. R. Weisbjerg, A. L. F. Hellwing, A. Bannink, and P. Lund. 2015. Methane production and diurnal variation measured in dairy cows and predicted from fermentation pattern and nutrient or carbon flow. Animal 9:1795-1806.

Brouwer, E. 1965. Report of sub-committee on constants and factors. Pages 441-443 in Energy Metabolism. Publication no. 11. K. L. Blaxter, ed. European Association for Animal Production, Ayr, Scotland.

Cammell, S. B., J. D. Sutton, D. E. Beever, D. J. Humphries, and R. H. Phipps. 2000. The effect of crop maturity on the nutritional value of maize silage for lactating dairy cows. 1. Energy and nitrogen utilization. Anim. Sci. 71:381-390.
Campbell, J. R., and C. P. Merilan. 1960. Effects of frequency of feeding on production characteristics and feed utilization in lactating dairy cows. J. Dairy Sci. 44:664-671.

Chase, L. E. 2014. Carbon footprint and the dairy industry. Pages 148-154 in Proc. Cornell Nutrition Conference. Cornell University, Ithaca, NY.

Crompton, L. A., J. A. N. Mills, C. K. Reynolds, and J. France. 2011. Fluctuations in methane emission in response to feeding pattern in lactating dairy cows. Pages 176-180 in Modelling Nutrient Digestion and Utilization in Farm Animals. D. Sauvant, J. Van Milgen, P. Faverdin, and N. Friggens, ed. Wageningen Academic Publishers, Wageningen, the Netherlands.

DeVries, T. J., and M. A. G. Von Keyserlingk. 2005. Time of feeding delivery affects the feeding and lying patterns of dairy cows. J. Dairy Sci. 88:625-631.

DRMS (Dairy Records Management System). 2014. DHI Glossary. DRMS, Raleigh, NC

DuBois, M., K. A. Giles, J. K. Hamiliton, P. A. Rebers, and F. Smith 1956. Colorimetric method for determination of sugars and related substances. Anal. Chem. 28:350-356.

Fenwick, M. A., S. Llewellyn, R. Fitzpatrick, D. A. Kenny, J. J. Murphy, J. Patton, and D. C. Wathes. 2008. Negative energy balance in dairy cows is associated with specific changes in IGF-binding protein expression in the oviduct. Reproduction 135:63-75.

Flatt, W. P., P. W. Moe, and R. R. Oltjen. 1967. Energy metabolism studies with dairy cows receiving purified diets. Pages 109-121 in Energy Metabolism of Farm Animals. Proc. 4th Symp. Energy Metab., Warsaw, Poland. K. L. Blaxter, ed. Academic Press, London, UK.

Foth, A. J., T. Brown-Brandl, K. J. Hanford, P. S. Miller, G. Garcia Gomez, and P. J. Kononoff. 2015. Energy content of reduced-fat dried distillers grains with solubles for lactating dairy cows. J. Dairy Sci. 98:7142-7152.

Freetly, H. C., J. A. Nienaber, and T. Brown-Brandl. 2006. Partitioning of energy during lactation of primiparous beef cows. J. Anim. Sci. 84:2157-2162.

Goering, H. K., and P. J. Van Soest. 1970. Forage Fiber Analysis. USDA Agricultural Research Service handbook no. 379. US Government Printing Office, Washington, DC.

Grant, R. 2009. Stocking density and time budgets. Pages $7-17$ in Proc. Western Dairy Management Conference. Accessed Sep. 11, 2018. http://wdmc.org/2009/Stocking\%20Density\%20\&\%20Time \%20Budgets.pdf.

Hales, K. E., and N. A. Cole. 2017. Hourly methane production in finishing steers fed at different levels of dry matter intake. J. Anim. Sci. 95:2089-2096.

Hall, M. B. 2009. Analysis of starch, including maltooligosaccharides, in animal feeds: A comparison of methods and a recommended method for AOAC collaborative study. J AOAC Int. 92:42-49.

Hart, K. D., B. W. McBride, T. F. Duffield, and T. J. DeVries. 2014 Effect of frequency of feed delivery on the behavior and productivity of lactating dairy cows. J. Dairy Sci. 97:1713-1724.

Hegarty, R. S. 2013. Applicability of short-term emission measurements for on-farm quantification of enteric methane. Animal $7: 401-408$

Heinrichs, A. J., and P. J. Kononoff. 2002. Evaluating particle size of forages and TMRs using the New Penn State Forage Particle Separator. Technical bulletin DAS 02-42. College Agric. Sci., Cooperative Ext., Pennsylvania State Univ., University Park, PA.

Hollmann, M., W. J. Powers, A. C. Fogiel, J. S. Liesman, and D. K. Beede. 2013. Response profiles of enteric methane emissions and lactational performance during habituation to dietary coconut oil in dairy cows. J. Dairy Sci. 96:1769-1781.

Kammel, D. W., J. M. Zulovich, and J. P. Harner. 2017. A systems approach to dairy farmstead design. Pages 167-184 in Large Dairy Herd Management. 3rd ed. D. K. Beede, ed. American Dairy Science Association, Champaign, IL.

Knapp, J. R., G. L. Laur, P. A. Vadas, W. P. Weiss, and J. M. Tricarico. 2014. Invited review: Enteric methane in dairy cattle production: Quantifying the opportunities and impact of reducing emissions. J. Dairy Sci. 97:3231-3261. 
Macmillan, K., X. Gao, and M. Oba. 2017. Increased feeding frequency increased milk fat yield and may reduce the severity of subacute ruminal acidosis in higher-risk cows. J. Dairy Sci. 100:1045-1054.

Moe, P. W., and H. F. Tyrrell. 1971. Net energy value for lactation of high- and low- protein diets containing corn silage. J. Dairy Sci. 55:288-303.

Moraes, L. E., E. Kebreab, A. B. Strathe, J. Dijkstra, J. France, D. P. Casper, and J. G. Fadel. 2015. Multivariate and univariate analysis of energy balance data from lactating dairy cows. J. Dairy Sci. 98:4012-4029.

National Research Council. 2001. Nutrient Requirements of Dairy Cattle. 7th rev. ed. Natl. Acad. Press, Washington, DC.

Nienaber, J. A., and A. L. Maddy. 1985. Temperature controlled multiple chamber indirect calorimeter-design and operation. Trans. ASAE 28:555-560.

Nocek, J. E., and D. G. Braund. 1985. Effect of feeding frequency on diurnal dry matter and water consumption, liquid dilution rate, and milk yield in first lactation. J. Dairy Sci. 68:2238-2247.

Purwanto, B. P., Y. Abo, R. Sakamoto, F. Furumoto, and S. Yamamoto. 1990. Diurnal patterns of heat production and heart rate under thermoneutral conditions in Holstein Friesian cows differing in milk production. J. Agric Sci. (Camb.) 114:139-142.

Reynolds, C. K., D. J. Humphries, P. Kirton, M. Kindermann, S. Duval, and W. Steinberg. 2014. Effects of 3-nitrooxypropanol on methane emission, digestion, and energy and nitrogen balance of lactating dairy cows. J. Dairy Sci. 97:3777-3789.

Shabi, Z., I. Bruckental, S. Zamwell, H. Tagari, and A. Arieli. 1999 Effects of extrusion of grain and feeding frequency on rumen fermentation, nutrient digestibility, and milk yield and composition in dairy cows. J. Dairy Sci. 82:1252-1260.

Tamura, T., H. Nakamura, S. Sato, M. Seki, and H. Nishiki. 2014 A modified catheterization procedure to reduce bladder damage when collecting urine samples from Holstein cows. J. Vet. Med. Sci. 76:819-826.

Tine, M. A., K. R. Mcleod, R. A. Erdman, and R. L. Baldwin. 2001. Effects of brown midrib corn silage on the energy balance of dairy cattle. J. Dairy Sci. 84:885-895.
Van Soest, P. J., J. B. Robertson, and B. A. Lewis. 1991. Methods for dietary fiber, neutral detergent fiber, and nonstarch polysaccharides in relation to animal nutrition. J. Dairy Sci. 74:3583-3597.

van Zijderveld, S. M., W. J. J. Gerrits, J. A. Apajalahti, J. R. Newbold, J. Dijkstra, R. A. Leng, and H. B. Perdok. 2010. Nitrate and sulfate: Effective alternative hydrogen sinks for mitigation of ruminal methane production in sheep. J. Dairy Sci. 93:5856-5866.

Vermorel, M., B. Remond, J. Vernet, and D. Liamadis. 1982. Utilization of body reserves by high-producing cows in early lactation; Effects of crude protein and amino-acid supply. Pages 18-21 in Energy Metabolism of Farm Animals. European Association for Animal Production publication no. 29. A. Ekern and F. Sundstøl, ed. EAAP, Ås, Norway.

Weiss, W. P. 1993. Predicting energy values of feeds. J. Dairy Sci. $76: 1802-1811$.

Weiss, W. P., L. B. Willett, N. R. St-Pierre, D. C. Borger, T. R. McKelvey, and D. J. Wyatt. 2009. Varying forage type, metabolizable protein concentration, and carbohydrate source affects manure excretion, manure ammonia, and nitrogen metabolism of dairy cows. J. Dairy Sci. 92:5607-5619.

Wildman, E. E., G. M. Jones, P. E. Wagner, R. L. Boman, H. F. Troutt, and T. N. Lesch. 1982. A dairy cow body condition scoring system and its relationship to selected production characteristics. J. Dairy Sci. 65:495-501.

Xue, B., T. Yan, C. F. Ferris, and C. S. Mayne. 2011. Milk production and energy efficiency of Holstein and Jersey-Holstein crossbred dairy cows offered diets containing grass silage. J. Dairy Sci. 94:1455-1464.

Yan, T., F. J. Gordon, R. E. Agnew, M. G. Porter, and D. C. Patterson. 1997. The metabolisable energy requirement for maintenance and the efficiency of utilization of metabolisable energy for lactation by dairy cows offered grass silage-based diets. Livest. Prod. Sci. 51:141-150 